\title{
Effects of low temperature-adapted Saccharomyces cerevisiae Y297 strain and fermentation temperature on the quality characteristics of Yakju
}

\author{
Dong-Jun Seo, Soo-Hwan Yeo, Ji-Young Mun, Seong Yeol Baek* \\ Department of Agro-food Resource, National Institute of Agricultural Science, RDA, Wanju 55365, Korea
}

\section{저온 적응성 효모와 발효온도에 따른 약주의 품질특성 변화}

\author{
서동준 · 여수환 · 문지영 · 백성열* \\ 농촌진흥청 국립농업과학원 농식품자원부
}

\begin{abstract}
The objective of this study was to evaluate the effects of low temperature-adapted Saccharomyces cerevisiae Y297 and fermentation temperatures on the quality of Yakju brewed. Physicochemical properties of Yakju brewed were compared $\mathrm{pH}$, total acidity, ethanol, free amino acid, organic acid contents, and volatile flavor compounds in $S$. cerevisiae Y297 with control treatment. Cooked non-glutinous rice and saccharogenic amylase in koji were mixed with ethanol-producing yeasts and then fermented at $15^{\circ} \mathrm{C}, 20^{\circ} \mathrm{C}$, and $25^{\circ} \mathrm{C}$ for 20 days. Yakju brewed using the Y297 treatment showed the highest ethanol yield $(17.9 \%)$ at $20^{\circ} \mathrm{C}$. Expression of heat shock protein (HSP) 104 was evaluated by immunoblotting as an indication of adaptation to low temperatures $\left(15^{\circ} \mathrm{C}\right)$; levels of the HSP104 protein were higher in the Y297 treatment than in the control. Organic acid analysis showed that the lactic acid content of Yakju brewed using the control was the highest at $25^{\circ} \mathrm{C}$. Finally, free amino acid analysis showed that the Y297 treatment had a higher proportion of essential amino acids than the control. Overall, these results indicate that $S$. cerevisiae Y297 could be used as a suitable yeast for Yakju brewed under low temperature $\left(15^{\circ} \mathrm{C}\right)$ condition.
\end{abstract}

Key words : low temperature, Saccharomyces cerevisiae, Yakju, fermentation, heat shock protein

서 론

우리나라 전통주인 탁주와 약주는 발효 과정 중에서 원 료인 쌀이 미생물에 의한 효소 작용에 의해 분해되어 lysine, leucine 등과 같은 필수아미노산과 비타민, 생리활성 물질 들과 당분, 유기산, 휘발성 향기성분 등을 생산하는 발효주 이다 $(1,2)$. 약주의 제조 과정은 누룩만을 이용하는 방식과 개량누룩에 효모를 첨가하는 방식으로 나눌 수 있는데(3) 이 제조 과정에서 효모는 발효 과정에서 당을 알코올로 전환하는 것뿐만 아니라 high alcohol, ester, vicinal

*Corresponding author. E-mail : dunkbis@korea.kr

Phone : 82-63-238-3609, Fax : 82-63-238-3843

Received 24 August 2016; Revised 15 October 2016; Accepted 24 October 2016.

Copyright (c) The Korean Society of Food Preservation. All rights reserved.
diketones(VDKs)등 다양한 휘발성 향미 성분과 대사산물의 생산에 있어서 중요한 역할을 한다고 알려져 있다(4). 최근 들어 술 제조 과정에서 알코올 생산뿐만 아니라 향과 맛에 중요성도 커지고 있다. 이러한 술의 품질의 중요 요소 중 하나인 온도는 효모의 생육과 알코올 생산에 있어서도 영향 을 준다. 효모의 저온발효에 대한 연구는 보통 cold shock라 부르는 $10 \sim 20^{\circ} \mathrm{C}$ 와 $10^{\circ} \mathrm{C}$ 이하(near freezing)에서의 cell growth, 발효 및 스트레스에 대한 실험 등이 보고되고 있다 (5). 저온발효 $\left(10 \sim 15^{\circ} \mathrm{C}\right)$ 는 primary aroma의 손실을 방지하 고 secondary aroma(ethyl과 acetate esters 등)의 합성을 증가 시키는 것으로 알려져 있다. 또한, 저온 발효 환경에서 효모 는 향기성분 관련 반응뿐만 아니라 단백질 전사, 세포막의 유동성, RNA구조의 안정성, 효소 활성 등 효모의 성장에 있어서 많은 영향을 준다고 보고되어지고 있다(6-7). 하지 만 저온에서의 발효는 향기 성분 증가와 안정성 증가 등의 
좋은 점도 있지만 이상발효나 균 성장 저해 등의 좋지 않는 반응이 일어날 수도 있기에 저온에서 생육 및 발효 활성이 우수한 저온 적응성 효모를 분리하여 발효에 이용하는 것이 저온발효에 유리할 것이다. 이러한 저온적응성 효모의 선 발은 약주 제조에 있어서 저온에서도 발효 활성이 높고 술의 품질을 높일 수 있는 물질을 생산하여 보다 질 높은 약주를 생산할 수 있을 것으로 기대된다. 효모의 저온적응 성에 대한 연구는 S. cerevisiae 균주의 저온에 대한 생육 및 효소 반응성과 온도관련 유전자들(CSF1, HSP104, LOT2, LTE1)에 대한 다양한 연구들이 보고되어지고 있다 $(4,8,9)$. 다양한 음식의 풍미 성분으로 알려져 있는 유기산과 알코올이 결합하여 만들어지는 ester는 발효주에서는 향기 성분의 주요 지표로써 사용되어진다. Acetate ester 계열인 ethyl acetate는 과일향이 나고 isoamyl acetate는 바나나향 그리고 phenylethyl acetate는 장미의 향기성분을 가지고 있 다고 알려져 있다. 또한 고급알코올의 일종인 n-propanol, isobutanol, isoamyl alchol은 알코올과 달콤함 향을 내는 주 요 성분으로 알려져 있다(4,10-12).

사전연구(13)에서 $\mathrm{Y} 297$ 균주는 $15^{\circ} \mathrm{C}$ 에서 접종 후 24 시간 동안은 $25^{\circ} \mathrm{C}$ 에 비해 낮았지만 배양 30 시간이후에는 $25^{\circ} \mathrm{C}$ 보 다 높은 생장곡선을 보였다. 또한 estrase, $\beta$-glucanse등의 향기관련 효소 활성이 다른 균주들에 비해 높은 값을 나타 내었다. 이러한 결과 등을 통해 Y297균주를 저온적응성 균주로 선발하여 다양한 발효 조건에서의 약주 품질에 대한 효과를 분석하였다.

\section{재료 및 방법}

\section{효모균주 및 원료}

본 실험에서 사용한 효모는 전국에서 수집한 메주, 누룩 등의 발효식품에서 분리한 균주들 중에서 저온적응성이 우수한 Saccharomyces cerevisiae Y297 균주를 사용하였다 (14). 비교균주로 시판효모인 Fermivin(S. cerevisiae, Oenobrands SAS, Narbonne, France)를 사용하였다. 실험에 사용된 효모 는 yeast extract $1 \%$, peptone $2 \%$, dextrose $2 \%$ (YPD, $\mathrm{BD}$, Franklin Lakes, NJ, USA) 액체배지에 배양 후, glycerol를 $20 \%$ 첨가하여 $-80^{\circ} \mathrm{C}$ 에서 보관하여 실험에 사용하였다. 멥 쌀은 2014년 9월 경기도 철원에서 재배된 것을 시중에서 구입하여 사용하였다.

\section{담금 및 발효}

멥쌀 $1 \mathrm{~kg}$ 을 수세하여 2시간 물에 침지한 후 1 시간 물 빼기 후 1 시간동안 증자하고 냉각한 후 입국과 물 $1.5 \mathrm{~L}$ 그리고 대조구와 선발효모를 증자한 쌀에 접종 후 각 온도 별 $\left(15^{\circ} \mathrm{C}, 20^{\circ} \mathrm{C}, 25^{\circ} \mathrm{C}\right)$ 로 20 일 발효하였다. 제조된 밑술은 원심분리 후 분석용 시료로 사용하였다.

\section{$\mathrm{pH}$ 및 총산}

$\mathrm{pH}$ 는 술덧 여액 $10 \mathrm{~mL}$ 를 취하여 $\mathrm{pH}$ meter(Orion star A211, Thermo, Walrham, MA, USA)로 측정하였다. 총산 함량은 상등액 $10 \mathrm{~mL}$ 를 페놀프탈레인 지시약 2 3방울을 넣은 후, $0.1 \mathrm{~N} \mathrm{NaOH}$ 용액으로 적정한 후 초산으로 환산하 였다.

\section{에탄올 및 아미노산도}

에탄올 함량은 시료 $100 \mathrm{~mL}$ 를 증류한 후, 주정계를 이용 하여 측정하였다(14). 아미노산도는 시료 $10 \mathrm{~mL}$ 에 페놀프 탈레인 지시약 2 3방울을 가하고 $0.1 \mathrm{~N} \mathrm{NaOH}$ 용액으로 중화한 후 중성포르말린 용액 $5 \mathrm{~mL}$ 를 넣은 후 $0.1 \mathrm{~N} \mathrm{NaOH}$ 용액으로 담홍색이 될 때까지 적정하여 측정하였다(15).

\section{샘플 준비 및 Western blotting}

효모는 YPD 액체배지에서 온도 $\left(15^{\circ} \mathrm{C}, 25^{\circ} \mathrm{C}\right)$ 에 따라 2 일 간 배양하여 원심분리 후 회수한 균체를 Yeast protein extraction buffer kit(GE healthcare, St. Louis, MO, USA)를 사용하여 단백질을 추출하였다. 추출된 단백질은 2-D Quant kit(GE healthcare, St. Louis, MO, USA)를 사용하여 단백질을 정량한 후 sodium dodecyl sulfate polyacrylamide gel electrophoresis(SDS-PAGE)로 단백질을 분리하였다. SDS- PAGE 겔은 Electric transfer kit(Mini Trans-Blot Electrophoretic Transfer Cell, Bio-Rad, Hercules, CA, USA)를 $100 \mathrm{~V}$ 에서 50분 동안 사용하여 polyvinylidene Difluoride (PVDF) membrane(Millipore, Billerica, MA, USA)로 단백질 을 옮겼다. 그 후 Blocking Solution(ATTO corporation, Tokyo, Japan)에 1시간 반응 후 1차 항체로 Anti-HSP104 ab69549(Abcam, Cambridge, UK)를 이용하여 1:5,000배로 희석하여 $4^{\circ} \mathrm{C}$ 에서 8 시간동안 반응하였다. 2 차 항체는 Goat Anti- rabbit $\operatorname{lgG}$ horseradish peroxidase ab6721(Abcam, Cambridge, $\mathrm{UK}$ )로 1:10,000배로 희석하여 125 도에서 1시간 반응한 후 Amersham imager 600(GE healthcare, St. Louis, $\mathrm{MO}, \mathrm{USA}$ )을 사용하여 밴드를 확인하였다.

\section{유기산과 유리아미노산 및 향기 성분 분석}

샘플은 약주를 원심 분리한 상등액 $5 \mathrm{~mL}$ 을 Sep-pak $\mathrm{C}_{18}$ cartridge에 통과시킨 후 $0.2 \mu \mathrm{m}$ 실린지 필터로 여과하여 HPLC(Chromaster 5000, Hitachi, Ltd., Tokyo, Japan)로 ODS-100W $(4.6 \mathrm{~mm} \times 250 \mathrm{~mm})$ column을 사용하여 유기산을 측정하였다. 유리아미노산은 충남대 공동실험실습관에 의 뢰하여 amino acid analyzer(L-8900, Hitachi Co., Tokyo, $\mathrm{Japan}$ 로 분석하였다(16). 향기분석은 $0.2 \mu \mathrm{m}$ 실린지 필터 로 여과된 샘플을 한국기초과학지원연구원 서울서부센터 의 GC Chromatograph/Mass Spectrometer(Agilent Technologies, Santa Clara, CA, USA)를 이용하여 분석하였다. 샘플은 Solid-phase microextraction (SPME) 방식으로 추출하여 분석 
하였다(17).

\section{통계처리}

실험결과의 통계처리는 3회 반복하여 평균(mean)과 표 준편차(SD)로 표시하였고 SPSS Statistic 24 통계프로그램 을 이용하여 일원배치 분산분석을 사용하여 $p<0.05$ 수준에 서 Duncan's multiple range test(DMRT)로 평균 간 다중비교 를 하였다.

\section{결과 및 고찰}

\section{저온적응성}

발효식품에서 분리한 효모들을 저온 $\left(15^{\circ} \mathrm{C}\right)$ 에서 배양하 여 저온적응성, 내성(알코올, 당, 염)등이 확인된 균주들을 동정하였고 향기관련 효소활성을 사전 연구(13)를 통해 확 인하였다. S. cerevisiae Y297의 저온적응성 특징을 확인하 기 위해 온도관련 단백질인 HSP104의 발현 정도를 확인하 였다. 실험균주로는 S. cerevisiae Y297와 대조구를 사용하 였고 온도는 $15^{\circ} \mathrm{C}$ 와 $25^{\circ} \mathrm{C}$ 에서 2 일간 배양한 후 단백질을 추출하여 $5 \mathrm{ug}$ 의 단백질 샘플을 SDS- PAGE와 Western

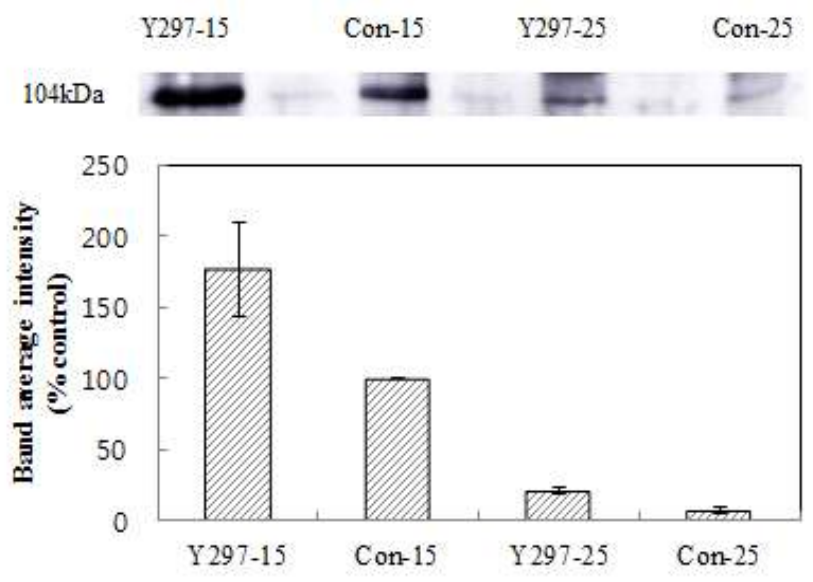

Fig. 1. Low temperature-induced HSP104 expression in Saccharomyces cerevisiae strain Y297 in YPD medium.

Primary antibody (HSP104) was tested for its ability to detect horseradish peroxidase-conjugated secondary antibody in cultured S. cerevisiae strain Y297. blot을 실시하였다(Fig. 1.) 그 결과, $15^{\circ} \mathrm{C}$ 에서의 S. cerevisiae Y297은 대조구에 비해 70\%이상 높은 HSP104 단백질 발현 을 보였고 $25^{\circ} \mathrm{C}$ 에서의 S. cerevisiae $\mathrm{Y} 297$ 은 대조구에 비해 $15 \%$ 이상 높은 발현 밴드를 확인할 수 있었다. Chiba 등(6)의 연구에서 CSF1, HSP12, HSP26, HSP104, LOT2, LTE1, $N R S 1, T C P 1, T I P$ 및 TIR2 유전자들에 대한 저온에서의 RNA 발현정도를 확인한 결과, CSF1, HSP104, TIR2 유전자 들이 저온 발효 시 발현정도가 증가하는 것으로 보고되고 있다. 또한 저온에서는 과오폴딩단백질(misfolded protein) 이나 응집 등을 유발한다고 보고되고 있는데 HSP104 단백 질은 이러한 스트레스를 감소시켜 저온에서 균 성장에 있어 서 유용한 유전자로 보고되고 있다 $(18,19)$.

\section{온도별 품질특성조사}

멥쌀과 입국 그리고 효모(대조구, S. cerevisiae Y297)를 혼합하여 온도별 $\left(15^{\circ} \mathrm{C}, 20^{\circ} \mathrm{C}, 25^{\circ} \mathrm{C}\right)$ 로 발효하여 성분을 분석 하였다(Table 1). $\mathrm{pH}$ 의 경우, 대조구는 온도가 높아질수록 $\mathrm{pH}$ 가 낮아졌지만 S. cerevisiae Y297 처리구의 경우 큰 차이 를 보이지 않았다. 총산도 역시, 대조구는 온도가 높아질수 록 산도가 높아졌지만 S. cerevisiae Y297 처리구의 경우 큰 차이를 보이지 않았다. Jin 등(20)과 Baek 등(21)의 연구 에 의하면 발효 온도가 올라갈수록 산의 생성도 많아진다고 보고되고 있다. 대조구의 경우 비슷한 양상을 보이지만 $S$. cerevisiae Y297 처리구는 통계적인 차이가 거의 없이 비슷 한 수치를 보였다. 아미노산도의 경우 S. cerevisiae Y297 처리구의 $20^{\circ} \mathrm{C}$ 에서 가장 높은 아미노산도를 보였다. 알코 올 함량은 전처리구에서 유의적인 차이를 보이지는 않았으 나 S. cerevisiae Y297로 $20^{\circ} \mathrm{C}$ 처리구에서 가장 높은 알코올 함량(17.9\%)을 나타내었다. Control 효모와 Y297 효모는 $15^{\circ} \mathrm{C}, 25^{\circ} \mathrm{C}$ 온도 조건에 알코올 함량이 각각 $16 \%, 15 \%$ 내외 로 나타났으며, $20^{\circ} \mathrm{C}$ 온도에서 알코올 함량이 $3 \%$ 정도 차이 가 발생하였다. 다양한 효모를 $25^{\circ} \mathrm{C}$ 에서 막걸리 발효한 후 의 알코올 함량은 $10.0 \sim 14.8 \%$ 이며 이는 효모의 특성으로 보고되었다(22).

\section{온도별 유기산 분석}

온도별 유기산 측정 결과(Table 2)는 oxalic acid, lactic acid, acetic acid, succinic acid의 총 4종류의 유기산이 검출

Table 1. Change of physicochemical properties of Yakju brewed at different fermentation temperatures $\left(15^{\circ} \mathrm{C}, 20^{\circ} \mathrm{C}\right.$, and $\left.25^{\circ} \mathrm{C}\right)$

\begin{tabular}{ccccccc}
\hline & \multicolumn{3}{c}{ Control } & & \multicolumn{2}{c}{ Y297 } \\
\cline { 2 - 7 } & $15^{\circ} \mathrm{C}$ & $20^{\circ} \mathrm{C}$ & $25^{\circ} \mathrm{C}$ & $15^{\circ} \mathrm{C}$ & $20^{\circ} \mathrm{C}$ & $25^{\circ} \mathrm{C}$ \\
\hline $\mathrm{pH}$ & $4.16 \pm 0.03^{\mathrm{a}, 1)}$ & $3.89 \pm 0.06^{\mathrm{a}}$ & $3.80 \pm 0.12^{\mathrm{a}}$ & $4.43 \pm 0.11^{\mathrm{a}}$ & $4.34 \pm 0.06^{\mathrm{b}}$ & $4.32 \pm 0.01^{\mathrm{b}}$ \\
Total acid (\%) & $0.30 \pm 0.01^{\mathrm{a}}$ & $0.47 \pm 0.04^{\mathrm{a}}$ & $0.53 \pm 0.10^{\mathrm{a}}$ & $0.25 \pm 0.05^{\mathrm{a}}$ & $0.31 \pm 0.01^{\mathrm{a}}$ & $0.28 \pm 0.01^{\mathrm{a}}$ \\
Amino acidity & $0.52 \pm 0.05^{\mathrm{a}}$ & $0.56 \pm 0.05^{\mathrm{a}}$ & $0.53 \pm 0.04^{\mathrm{a}}$ & $0.70 \pm 0.10^{\mathrm{b}}$ & $1.24 \pm 0.06^{\mathrm{b}}$ & $0.53 \pm 0.01^{\mathrm{a}}$ \\
Ethanol (\%) & $16.17 \pm 0.32^{\mathrm{a}}$ & $14.30 \pm 0.17^{\mathrm{a}}$ & $15.23 \pm 0.31^{\mathrm{a}}$ & $16.37 \pm 0.57^{\mathrm{a}}$ & $17.90 \pm 0.36^{\mathrm{b}}$ & $15.43 \pm 0.40^{\mathrm{a}}$ \\
\hline
\end{tabular}

${ }^{1)}$ Values are mean \pm SD $(n=3), p<0.05$. 
Table 2. Change of organic acid of Yakju brewed at different fermentation temperatures $\left(15^{\circ} \mathrm{C}, 20^{\circ} \mathrm{C}\right.$, and $\left.25^{\circ} \mathrm{C}\right)$

(unit: $\mathrm{mg} / \mathrm{mL}$ )

\begin{tabular}{ccccccc}
\hline \multirow{2}{*}{ Organic acid } & \multicolumn{3}{c}{ Control } & \multicolumn{3}{c}{ Y297 } \\
\cline { 2 - 7 } & $15^{\circ} \mathrm{C}$ & $20^{\circ} \mathrm{C}$ & $25^{\circ} \mathrm{C}$ & $15^{\circ} \mathrm{C}$ & $20^{\circ} \mathrm{C}$ & $25^{\circ} \mathrm{C}$ \\
\hline Oxalic acid & $0.09 \pm 0.01^{\mathrm{a} 1)}$ & $0.12 \pm 0.02^{\mathrm{a}}$ & $0.13 \pm 0.01^{\mathrm{a}}$ & $0.17 \pm 0.02^{\mathrm{a}}$ & $0.20 \pm 0.01^{\mathrm{b}}$ & $0.17 \pm 0.02^{\mathrm{b}}$ \\
Lactic acid & $1.23 \pm 0.01^{\mathrm{a}}$ & $2.77 \pm 0.01^{\mathrm{b}}$ & $3.78 \pm 1.13^{\mathrm{b}}$ & $1.51 \pm 0.41^{\mathrm{a}}$ & $0.83 \pm 0.21^{\mathrm{a}}$ & $1.03 \pm 0.04^{\mathrm{a}}$ \\
Acetic acid & $0.27 \pm 0.04^{\mathrm{a}}$ & $1.91 \pm 0.15^{\mathrm{a}}$ & $1.81 \pm 0.26^{\mathrm{b}}$ & $1.96 \pm 0.45^{\mathrm{a}}$ & $0.24 \pm 0.01^{\mathrm{b}}$ & $\mathrm{ND}^{\mathrm{a} 2)}$ \\
Succinic acid & $0.98 \pm 0.01^{\mathrm{a}}$ & $1.15 \pm 0.02^{\mathrm{a}}$ & $1.15 \pm 0.02^{\mathrm{a}}$ & $0.59 \pm 0.16^{\mathrm{a}}$ & $1.13 \pm 0.12^{\mathrm{b}}$ & $1.2 \pm 0.03^{\mathrm{b}}$ \\
\hline
\end{tabular}

${ }^{1)}$ Values are mean $\pm \mathrm{SD}(\mathrm{n}=3)$.

${ }^{2)} \mathrm{ND}$, Not detected, $\mathrm{p}<0.05$

되었다. Lactic acid는 대조구의 $15^{\circ} \mathrm{C}$ 에서 $1.23 \pm 0.01 \mathrm{mg} / \mathrm{L}$ 이 고 $20^{\circ} \mathrm{C}$ 와 $25^{\circ} \mathrm{C}$ 에서는 각각 $2.77 \pm 0.01 \mathrm{mg} / \mathrm{L}$ 과 $3.78 \pm 1.13$ $\mathrm{mg} / \mathrm{L}$ 으로 유의적인 차이는 보이지 않았으나 온도에 따라 증가하는 경향을 보였다. S.cerevisiae Y297 처리구에서는 모든 온도에서 유의적인 차이가 보이지 않았다. Baek 등 (21)의 실험에서 $20^{\circ} \mathrm{C}$ 와 $30^{\circ} \mathrm{C}$ 에서 발효한 술덧의 lactic acid 양을 확인한 결과 $20^{\circ} \mathrm{C}$ 에서 보다 많은 양이 검출되었는데 이는 온도 조건에 영향을 받은 것으로 보고되고 있다. 본 실험에서는 비슷한 결과를 보인 대조구와 달리 $S$ cerevisiae Y297 처리구는 모든 온도에서 lactic acid의 양이 큰 차이를 보이지 않았다(Table 2). 또한, 대조구의 succinic acid는 lactic acid와 비슷한 경향을 보였지만 S. cerevisiae Y297 처리구는 온도에 따라 검출량이 증가하는 경향을 보였다. 약주에서 검출되는 lactic acid는 막걸리의 주요 유기산이며 향미에 좋은 않는 영향을 주는 것으로 보고되었다(23). Bang 등(24)은 효모종류에 따른 막걸리의 유기산 특성에서 사용한 Fermivin 효모는 $522.4 \mathrm{mg} / \mathrm{L}$ 로 보고하였다. 본 연구 에서는 lactic acid 함량이 다소 낮았지만 $20^{\circ} \mathrm{C}, 25^{\circ} \mathrm{C}$ 에서 대조군보다 $\mathrm{Y} 297$ 효모의 함량이 약 3 배 정도 낮게 검출되어 약주의 향미가 대조군보다 좋을 것으로 판단된다. Acetic acid는 lactic acid와 같이 막걸리 향미에 좋지 않는 영향을 미치는 것으로 알려져 있으며(23), 막걸리의 주요 유기산 중 하나이다. 대조군은 $15^{\circ} \mathrm{C}$ 에서 acetic acid 함량이 가장 낮았으며, $\mathrm{Y} 297$ 은 $20^{\circ} \mathrm{C}, 25^{\circ} \mathrm{C}$ 에서 함량이 낮았다. 쌀 막걸리 의 주된 유기산 중 하나인 succinic acid은 Lee 등(25)이 보고한 연구에서 막걸리 발효 과정 중 주요한 유기산으로 확인되었다. 위 유기산 함량을 종합하였을 때 acetic acid, lactic acid 함량은 낮고 succinic acid 함량은 높은 Y297로 $20^{\circ} \mathrm{C}$ 발효한 것으로 판단된다.

\section{온도별 유리 아미노산 분석}

발효온도에 따른 유리아미노산의 생성정도를 분석한 결 과(Table 3), 대조구의 경우는 온도에 따른 유리아미노산의 생산량이 통계적으로 유의한 차이를 보이지 않았다. $\boldsymbol{S}$. cerevisiae Y297 처리구에서는 $20^{\circ} \mathrm{C}$ 에서 발효된 조건에서 $1,040.48 \pm 64.20 \mathrm{mg} / \mathrm{L}$ 로 가장 높은 유리아미노산을 생산하
는 것으로 나타났다. Baek 등(21)과 Woo 등(26)의 실험에서 는 온도가 높아지면서 유리아미노산의 함량도 높아지는 것으로 나타났지만 S. cerevisiae Y297 처리구에서는 $20^{\circ} \mathrm{C}$ 조건에서 가장 높은 유리아미노산 농도를 보였다. 이러한 결과는 품질분석과 유기산 및 유리아미노산의 전반적인 결과에서도 S.cerevisiae Y297 처리구의 $15^{\circ} \mathrm{C}$ 및 $20^{\circ} \mathrm{C}$ 에서도 비슷한 결과를 확인할 수 있었다. 이러한 결과들을 통해 대조구에 비해 $\mathrm{Y} 297$ 처리구는 $15^{\circ} \mathrm{C}$ 와 $20^{\circ} \mathrm{C}$ 에서 발효 과정 중 품질 특성에서 큰 영향을 주지 않는 것으로 확인되었다. 이는 Y297균주가 저온 발효를 통해 술의 품질과 향에 영향 을 주는 성분들의 손실을 낮추면서 발효 효율을 유지할 수 있는 저온적응성 균주를 확보하려는 목적에 부합하는 균주임을 확인할 수 있었다.

Kang 등(27)은 쌀 및 쌀 전분을 활용한 약주의 품질특성 연구에서 쌀약주의 유리아미노산이 498.38 5,976.93 ppm 검출된다고 보고하였다. 주류에 아미노산이 적으면 맛이 가볍고, 많으면 잡미가 증가하여 품질을 저하시키기 때문 에 적정한 함량을 유지하는 것이 중요하나 최적 함량에 대해서는 아직 밝혀진 바는 없다. 아미노산은 발효과정 중 효모의 대사에 의하여 고급알코올(fusel oil)로 변환되어 주 류의 향기를 부여하기도 하며, 아미노산 산화효소 및 아미 노산 탈수효소에 의하여 oxalic acid로 변하여 맛의 변화를 주기도 한다(28).

\section{온도별 향기성분 분석}

사전연구를 통해 향기성분에 대한 정성분석결과 처리구 당 50 종 내외의 향기관련 물질들이 검출되었다. 본 실험에 서는 이 성분들 중 대표적인 6개의 향기성분[ethyl acetate, 1-propanol, 1-butanol(3-methyl-, acetate), 1-propanol(3-methyl-), acetic acid, phenylethyl alcohol]에 대해 온도별로 향기성분 을 측정한 결과(Table 4)이다. S cerevisiae Y297 처리구에 서는 약주의 주요 향기성분 중 하나로 과일향이 난다고 알려져 있는 ethyl acetate이 $41.46 \pm 0.54 \mathrm{mg} / \mathrm{L}$ 로 가장 높은 수치를 보였고 Higher alcohol 중의 하나이며 감미성의 바나 나향을 갖고 있는 1-butanol(3-methyl-)와 phenylethylalanine 으로 부터 유래한 성분으로 와인, 위스키등의 다양한 주류 
Table 3. Change of free amino acid of Yakju brewed at different fermentation temperatures $\left(15^{\circ} \mathrm{C}, 20^{\circ} \mathrm{C}\right.$, and $\left.25^{\circ} \mathrm{C}\right)$

(unit: $\mathrm{mg} / \mathrm{L}$ )

\begin{tabular}{|c|c|c|c|c|c|c|c|}
\hline & & \multicolumn{3}{|c|}{ Control } & \multicolumn{3}{|c|}{ Y297 } \\
\hline & & $15^{\circ} \mathrm{C}$ & $20^{\circ} \mathrm{C}$ & $25^{\circ} \mathrm{C}$ & $15^{\circ} \mathrm{C}$ & $20^{\circ} \mathrm{C}$ & $25^{\circ} \mathrm{C}$ \\
\hline \multirow{8}{*}{ Essential amino acid } & Isoleucine & $8.35 \pm 2.23^{1)}$ & $6.85 \pm 0.20$ & $8.61 \pm 1.63$ & $17.04 \pm 7.59$ & $28.55 \pm 2.96$ & $6.96 \pm 0.18$ \\
\hline & Leucine & $25.15 \pm 3.59$ & $26.32 \pm 2.20$ & $26.68 \pm 3.13$ & $50.24 \pm 7.19$ & $101.70 \pm 8.18$ & $28.97 \pm 0.81$ \\
\hline & Methionine & $5.95 \pm 3.33$ & $2.51 \pm 0.21$ & $2.07 \pm 0.65$ & $7.61 \pm 0.95$ & $10.25 \pm 1.75$ & $1.36 \pm 0.25$ \\
\hline & Valine & $15.54 \pm 1.67$ & $16.67 \pm 0.71$ & $19.90 \pm 5.31$ & $24.93 \pm 5.05$ & $57.82 \pm 4.70$ & $14.77 \pm 0.73$ \\
\hline & Threonine & $3.47 \pm 0.38$ & $3.19 \pm 0.21$ & $3.30 \pm 1.62$ & $7.69 \pm 3.60$ & $24.08 \pm 4.22$ & $4.21 \pm 0.71$ \\
\hline & Phenylalanine & $17.63 \pm 1.96$ & $20.34 \pm 1.67$ & $17.26 \pm 0.64$ & $36.31 \pm 7.10$ & $71.21 \pm 5.90$ & $20.75 \pm 1.07$ \\
\hline & Lysine & $14.06 \pm 0.48$ & $9.55 \pm 0.21$ & $5.87 \pm 0.35$ & $20.70 \pm 2.75$ & $28.79 \pm 3.40$ & $15.20 \pm 0.25$ \\
\hline & Total & $90.15 \pm 13.48$ & $86.00 \pm 5.50$ & $86.04 \pm 14.01$ & $154.20 \pm 29.65$ & $322.40 \pm 25.23$ & $92.23 \pm 2.90$ \\
\hline \multirow{8}{*}{$\begin{array}{l}\text { Nonessential amino } \\
\text { acid }\end{array}$} & Arginine & $73.36 \pm 1.62$ & $34.32 \pm 3.22$ & $22.88 \pm 4.36$ & $73.90 \pm 17.96$ & $69.51 \pm 4.41$ & $39.76 \pm 1.73$ \\
\hline & Histidine & $11.01 \pm 0.87$ & $2.83 \pm 0.33$ & $1.06 \pm 0.12$ & $11.16 \pm 8.55$ & $12.13 \pm 0.81$ & $5.93 \pm 0.14$ \\
\hline & Aspartic acid & $8.17 \pm 0.69$ & $13.11 \pm 2.39$ & $7.46 \pm 0.05$ & $26.37 \pm 7.95$ & $39.00 \pm 5.80$ & $9.93 \pm 0.41$ \\
\hline & cysteine & $11.21 \pm 3.33$ & $3.05 \pm 0.89$ & $3.52 \pm 0.26$ & $12.43 \pm 1.01$ & $19.65 \pm 1.54$ & $23.79 \pm 1.97$ \\
\hline & Serine & $7.37 \pm 0.93$ & $6.85 \pm 0.51$ & $5.96 \pm 0.83$ & $19.52 \pm 8.48$ & $54.89 \pm 5.98$ & $10.96 \pm 1.27$ \\
\hline & Glutamine acid & $32.21 \pm 1.03$ & $20.82 \pm 0.61$ & $44.00 \pm 30.65$ & $52.42 \pm 19.56$ & $95.76 \pm 0.11$ & $35.11 \pm 0.23$ \\
\hline & Tyrosine & $12.96 \pm 2.08$ & $16.61 \pm 0.63$ & $10.60 \pm 1.92$ & $25.16 \pm 4.36$ & $58.16 \pm 4.55$ & $15.53 \pm 1.00$ \\
\hline & Total & $156.30 \pm 9.00$ & $104.07 \pm 10.54$ & $128.07 \pm 17.70$ & $202.05 \pm 49.87$ & $355.03 \pm 24.84$ & $137.88 \pm 1.39$ \\
\hline \multirow{13}{*}{$\begin{array}{l}\text { Amino acid } \\
\text { derivative }\end{array}$} & ४ -Amino-n-butyric acid & $6.88 \pm 1.14$ & $0.90 \pm 0.23$ & $3.14 \pm 1.27$ & $5.65 \pm 2.66$ & $38.16 \pm 4.60$ & $8.20 \pm 1.04$ \\
\hline & Ethanol amine & $3.43 \pm 0.78$ & $1.87 \pm 0.22$ & $1.48 \pm 0.04$ & $5.07 \pm 0.70$ & $6.33 \pm 0.81$ & $8.18 \pm 0.57$ \\
\hline & Ammonia & $3.75 \pm 0.26$ & $6.44 \pm 0.46$ & $6.70 \pm 0.37$ & $6.95 \pm 1.04$ & $12.54 \pm 0.37$ & $4.28 \pm 1.23$ \\
\hline & Ornithine & $21.35 \pm 0.90$ & $7.71 \pm 0.87$ & $6.74 \pm 0.15$ & $34.16 \pm 4.11$ & $50.34 \pm 6.74$ & $26.00 \pm 3.49$ \\
\hline & 3-Methylhistidine & $2.08 \pm 1.80$ & $\mathrm{ND}^{2)}$ & ND & $4.75 \pm 0.80$ & $\mathrm{ND}$ & $\mathrm{ND}$ \\
\hline & Phospho-serine & $7.02 \pm 0.19$ & $7.70 \pm 0.21$ & $7.62 \pm 0.54$ & $7.21 \pm 0.66$ & $10.71 \pm 0.10$ & $7.99 \pm 0.15$ \\
\hline & Taurine & $72.11 \pm 1.52$ & $56.45 \pm 0.94$ & $57.74 \pm 1.09$ & $72.24 \pm 4.26$ & $54.43 \pm 1.91$ & $47.91 \pm 0.33$ \\
\hline & Urea & $15.67 \pm 2.08$ & $\mathrm{ND}$ & ND & ND & $9.62 \pm 0.544$ & $\mathrm{ND}$ \\
\hline & Glycin & $17.53 \pm 1.33$ & $14.02 \pm 0.42$ & $9.39 \pm 4.17$ & $22.70 \pm 5.36$ & $47.92 \pm 3.77$ & $13.56 \pm 2.28$ \\
\hline & Alanine & $45.93 \pm 0.66$ & $36.56 \pm 1.20$ & $27.28 \pm 3.70$ & $92.18 \pm 21.33$ & $125.07 \pm 6.54$ & $57.26 \pm 4.65$ \\
\hline & Citruline & $1.22 \pm 0.13$ & ND & $\mathrm{ND}$ & $4.22 \pm 5.72$ & $5.57 \pm 2.67$ & $\mathrm{ND}$ \\
\hline & L-Cystathionine & $5.13 \pm 2.22$ & $0.77 \pm 0.11$ & $0.55 \pm 0.41$ & $6.51 \pm 3.24$ & $2.34 \pm 0.76$ & $1.16 \pm 0.18$ \\
\hline & Total & $202.09 \pm 6.90$ & $132.42 \pm 0.91$ & $126.47 \pm 20.16$ & $251.34 \pm 32.28$ & $363.04 \pm 16.63$ & $174.55 \pm 12.07$ \\
\hline \multicolumn{2}{|r|}{ Total } & $448.53 \pm 29.00$ & $322.49 \pm 16.08$ & $349.41 \pm 50.27$ & $607.58 \pm 111.79$ & $1,040.48 \pm 64.20$ & $404.66 \pm 16.24$ \\
\hline
\end{tabular}

${ }^{1)}$ Values are mean \pm SD $(\mathrm{n}=3)$.

${ }^{2)} \mathrm{ND}$, Not detected.

Table 4. Change of volatile flavor compounds of Yakju brewed at different fermentation temperatures $\left(15^{\circ} \mathrm{C}, 20^{\circ} \mathrm{C}\right.$, and $\left.25^{\circ} \mathrm{C}\right)$

\begin{tabular}{lcccccc} 
& \multicolumn{1}{c}{ (unit: mg/L) } \\
\hline & \multicolumn{3}{c}{ Compounds } & \multicolumn{1}{c}{ Control } & & \multicolumn{2}{c}{ Y297 } \\
\cline { 2 - 7 } & $175^{\circ} \mathrm{C}$ & $20^{\circ} \mathrm{C}$ & $25^{\circ} \mathrm{C}$ & $15^{\circ} \mathrm{C}$ & $20^{\circ} \mathrm{C}$ & $25^{\circ} \mathrm{C}$ \\
\hline Ethyl Acetate & $17.20 \pm 4.30^{1)}$ & $12.03 \pm 1.28$ & $15.42 \pm 4.52$ & $41.46 \pm 0.54$ & $9.30 \pm 2.21$ & $17.20 \pm 6.36$ \\
1-Propanol & $55.59 \pm 16.94$ & $21.31 \pm 8.81$ & $30.50 \pm 3.49$ & $9.21 \pm 3.77$ & $15.86 \pm 6.12$ & $27.09 \pm 8.94$ \\
1-Propanol, 2-methyl- & $63.30 \pm 16.93$ & $68.09 \pm 8.61$ & $64.25 \pm 18.60$ & $32.19 \pm 4.41$ & $84.90 \pm 16.60$ & $95.24 \pm 61.21$ \\
1-Butanol, 3-methyl-, acetate & $0.08 \pm 0.29$ & $0.04 \pm 0.02$ & $0.05 \pm 0.01$ & $0.03 \pm 0.01$ & $0.07 \pm 0.03$ & $0.06 \pm 0.01$ \\
1-Butanol, 3-methyl- & $69.67 \pm 11.71$ & $58.96 \pm 8.90$ & $55.28 \pm 8.30$ & $41.96 \pm 0.29$ & $85.09 \pm 14.74$ & $58.88 \pm 5.26$ \\
Phenylethyl Alcohol & $14.35 \pm 2.35$ & $11.13 \pm 3.01$ & $11.83 \pm 3.31$ & $13.88 \pm 3.28$ & $17.01 \pm 6.56$ & $11.05 \pm 1.71$ \\
\hline
\end{tabular}

\footnotetext{
${ }^{1)}$ Values are mean \pm SD $(n=3)$.
} 
에서 중요한 방향족 알코올 성분으로 알려진 phenylethyl Alcohol은 각각 $41.96 \pm 0.29 \mathrm{mg} / \mathrm{L}$ 과 $13.88 \pm 3.28 \mathrm{mg} / \mathrm{L}$ 의 수 치를 보였다. 안 등(29)의 실험에서 막걸리는 1-butanol (3-methyl-)과 phenylethyl Alcohol이 각각 $3.28 \mathrm{mg} / \mathrm{L}$ 와 $225.68 \mathrm{mg} / \mathrm{L}$ 로 검출된다고 보고하였다.

\section{요 약}

본 실험은 약주 제조 과정에서 효모와 발효온도에 따른 약주의 품질을 분석하였다. 약주의 이화학적 특성 $(\mathrm{pH}$, 총 산, 에탄올, 유리 아미노산, 유기산, 향기 성분)을 조사하였 다. 약주는 증자된 멥쌀에 입국과 효모를 넣고 각기 다른 온도 $\left(15^{\circ} \mathrm{C}, 20^{\circ} \mathrm{C}, 25^{\circ} \mathrm{C}\right)$ 에서 20 일간 발효하였다. $20^{\circ} \mathrm{C}$ 에서 발효한 S. cerevisiae Y297 처리구는 다른 처리구에 비해 높은 알코올 생산성(17.9\%)을 보였다. 온도관련 항체인 HSP104를 이용하여 면역반응을 확인한 결과, S. cerevisiae Y297 처리구는 대조구에 비해 저온에서 HSP104 단백질의 발현율이 높게 나타났다. 유기산 분석 결과, 대조구의 $25^{\circ} \mathrm{C}$ 에서 젖산의 함량이 높게 분석되었다. 유리아미노산 분석 결과, 저온에서 S. cerevisiae Y297 처리구는 대조구에 비해 높은 필수 아미노산량을 확인할 수 있었다. 이러한 결과들 을 통해 S. cerevisiae Y297 균주가 저온에서 제조하는 약주 생산에 사용할 수 있는 효모로써의 가능성을 확인할 수 있었다.

\section{감사의 글}

본 연구는 농촌진흥청 공동연구사업(과제번호:PJ00999001) 의 지원에 의해 이루어진 것이며, 연구비 지원에 감사드립 니다.

\section{References}

1. Huh CK, Lee JW, Kim YD (2013) Comparison of the organic acids, fusel oil contents and antioxidant activities of Yakju with the additions of various rice cultivars. Korean J Food Preserv, 20, 365-371

2. Kim MJ, Kim BH, Han JK, Lee SY, Kim KS (2011) Analysis of quality properties and fermentative microbial profiles of Takju and Yakju brewed with or without steaming process. J Food Hyg Safety, 26, 64-69

3. Bae SM, Lee YH, Lee MK, Kang SA, Cheongand C (2008) Effects of traditional Nuruk ration yeast on the fermentation and quality of Yakju. J East Asian Soc
Dietary Life, 18, 41-48

4. Pires EJ, Teixeira JA, Branyik T, Vicente AA (2014) Yeast: the soul of beer's aroma-a review of flavour-active esters and higher alcohols produced by brewing yeast. Appl Microbiol Biotechnol, 98, 1937-1949

5. Beltran G, Rozes N, Mas A, Guillamon JM (2007) Effect of low-temperature fermentation on yeast nitrogen metabolism. World J Microbiol Biotechnol, 23, 809-815

6. Chiva R, Lopez-malo M, Salvado Z, Mas A, Guillamón JM (2012) Analysis of low temperature-induced gene (LTIG) in wine yeast during alcoholic fermentation. FEMS Yeast Res, 12, 831-843

7. Torija MJ, Rozes N, poblet M, Guillamon JM, Mas A (2003) Effects of fermentation temperature on the strain population of Sacchromyces cerevisiae. Int J Food Microbiol, 80, 47-53

8. Schade B, Jansen G, Whiteway M, Entian KD, Thomas DY (2004) Clod adaption in budding yeast. Mol biol Cell, 15, 5492-5502

9. Aguilera J, Randez-Gil F, Prieto JA (2007) Cold response in Sacchromyces cerevisiae: new functions for old mechanisms. FEMS Microbiol Rev, 31, 327-341

10. Verstrepen KJ, Van Laere SDM, Vanderhaegen BMP, Derdelinckx G, Dufour JP, Pretorius IS (2003) expression levels of the yeast alcohol acetyltransferase genes ATF1, $\mathrm{Lg}-A T F$, and $A T F 2$ control the formation of a broad range of volatile esters. Appl Environ Microbiol, 69, 5228-5237

11. Baek SY, Lee YJ, Kim JH, Yeo SH (2015) Isolation and characterization of wild yeasts for improving liquor flavors style and quality. Microbiol Biotechnol Lett, 43, 1-9

12. Ichikawa E, Hosokawa N, Hata Y, Abe Y, Suginami K, Imayasu S (1991) Breeding of sake yeast with improved ethyl caproate productivity. Agric Biol Chem, 55, 2153-2154

13. Seo DJ, Yeo SH, Mun JY, Jung WJ, Cho YS, Baek SY (2015) Characteristics of yeast with low temperature adaptation for Yakju brewed. Korean J Food Preserv, 22, 908-914

14. Jung HK, Park CD, Park HH, Lee GD, Lee IS, Hong $\mathrm{JH}$ (2006) Manufacturing and characteristic of Korea traditional liquor, Hahyangju prepared by Sacchromyces cerevisiae HA3 isolated from traditional Nuruk Korean J Food Sci Technol, 38, 659-667

15. Park JH, Yeo SH, Choi JH, Jeong ST, Choi HS (2012) Production of Makgeolli using rice treated with Gaeryang-Nuruk (for Non-steaming Process) extract. 
Korean J Food Preserv, 19, 144-152

16. Shim JS, Jeong YJ (2003) Change in the components of acetic acid fermentation of brown rice using raw starch digesting enzyme. J Korean Soc Food Sci Nutr, 23, 381-387

17. Martos PA, Pawliszyn J (1997) Calibration of solid phase microextraction for air analyses based on physical chemical properties of the coating. Anal Chem, 69, 206-215

18. Al-Fageeh MB, Smales CM (2006) Control and regulation of the cellular responses to cold shock: the responses in yeast and mammalian systems. Biochem J, 397, 247-259

19. Bosl B, Grimminger V, Walter S (2006) The molecular chaperone HSP 104-A molecular machine for protein disaggregation. J Struct Biol, 156, 139-148

20. Jin TY, Chung HJ, Eun JB (2006) The effect of fermentation temperature on the quality of Jinyangju, Korean traditional rice wine. Korean J Food Sci Technol, 38, 414-418

21. Baek CH, Choi JH, Choi HS, Jeong ST, Kim JH, Jeong YJ, Yeo SH (2013) Quality characteristic of brown rice Makgeolli produced under differing conditions. Korean J Microbiol Biotechnol, 41, 168-175

22. Kang HR, Lee AR, Kwon YH, Kim JH, Kim HR, Ahn BH (2012) Optimization of culture conditions for the yeast and analysis of qualities of Makgeolli brewed with the yeast isolated from Korean traditional Nuruk Kor J Mycol, 40, 204-209
23. Kim DR, Seo BM, Noh MH, Kim YW (2012) Comparison of temperature effects on brewing of Makgeolli using uncooked germinated black rice. Korean Soc Biotechnol Bioeng J, 27, 251-256

24. Bang CM, Moon JK, Hong SK (2016) Characteristics of organic acid of Makgeolli by yeast strains type. Korean J Food Cook Sci, 32, 44-49

25. Lee YJ, Yi HC, Hwang KT, Kim DH, Kim HJ, Jung CM, Choi YH. (2012) The qualities of Makgeolli (Korean rice wine) made with different rice cultivars, milling degrees of rice, and Nuruks. J Korean Soc Food Sci Nutr, 41, 1785-1791

26. Woo SM, Shin JS, Seong JH, Yeo SH, Choi JH, Kim TY, Jeong YJ (2010) Quality characteristics of brown rice Makgeolli by different Nuruks. J Korean Soc Food Sci Nutr, 39, 301-307

27. Kang JE, Kim JW, Choi HS, Kim CW, Yeo SH, Jeong ST (2015) Quality characteristics of rice and rice starch-based Yakju. Korean J Food Preserv, 22, 353-360

28. Erasmus DJ (2005) Production of acetic acid by Saccharomyces cerevisiae during icewine fermentations. $\mathrm{Ph}$ D Thesis, University of British Colombia, Vancouver, Canada

29. Ahn YG, Song YS, Shin JH (2012) Determination of the volatile flavor compounds for the quality characteristics in traditional alcoholic beverages. Korean J Community Living Sci, 23, 199-206 